\title{
Review
}

\section{ROLE OF SALICYLIC ACID IN ACCLIMATION TO LOW TEMPERATURE}

\author{
M. PÁL, O. K. GONDOR and T. JANDA \\ AGRICULTURAL INSTITUTE, CENTRE FOR AGRICULTURAL RESEARCH, HUNGARIAN \\ ACADEMY OF SCIENCES, MARTONVÁSÁR, HUNGARY \\ Received: 25 January, 2013; accepted: 22 March, 2013
}

\begin{abstract}
Low temperature is one of the most important limiting factors for plant growth throughout the world. Exposure to low temperature may cause various phenotypic and physiological symptoms, and may result in oxidative stress, leading to loss of membrane integrity and to the impairment of photosynthesis and general metabolic processes. Salicylic acid (SA), a phenolic compound produced by a wide range of plant species, may participate in many physiological and metabolic reactions in plants. It has been shown that exogenous SA may provide protection against low temperature injury in various plant species, while various stress factors may also modify the synthesis and metabolism of SA. In the present review, recent results on the effects of SA and related compounds in processes leading to acclimation to low temperatures will be discussed.
\end{abstract}

Key words: acclimation, chilling, cold, freezing, plant, salicylic acid, stress

\section{Introduction}

More than half of all known plant species live in the tropical and subtropical regions of the world (Lukatkin et al., 2012). Thus, most of these species die or suffer severe damage at temperatures between 0 and $15^{\circ} \mathrm{C}$ (chilling stress) or, at the least, chilling temperatures lead to a reduction in productivity if the plants are grown in temperate climates. The ability of plants to survive chilling temperatures without injury to their future growth and development is known as cold resistance. Although plants from temperate regions are chilling tolerant, most of them have little tolerance to freezing. Their freezing tolerance is improved, however, by cold hardening processes, when they are exposed to low, but non-freezing temperatures for a certain period. By contrast, plants of tropical and subtropical origin, such as maize, are sensitive to chilling stress and are not capable of cold acclimation. Chilling stress causes various phenotypic symptoms, including reduced leaf expansion, wilting, 
chlorosis, necrosis and the inhibition of reproductive development, and also results in oxidative stress, leading to loss of membrane integrity, and to the reduction or impairment of photosynthesis and general metabolic processes. In contrast, the major effect of freezing is severe membrane damage, which is largely due to ice formation rather than to the acute dehydration and cell damage induced by low temperature.

The exposure of plants to low temperature stress leads to the modification of the metabolism in two ways. First, the plants try to adjust to the altered cellular metabolism caused by unfavourable temperatures. Secondly, modifications in the metabolism in response to temperature stress are mainly linked to enhanced tolerance mechanisms (Yadav, 2010). Many metabolic changes are thought to have an important role in cold stress tolerance. During cold acclimation the proportion of unsaturated fatty acids increases (Szalai et al., 2001). Besides alterations in the quantity of unsaturated fatty acids, the composition of glycerolipids, proteins and carbohydrates also changes. Particular interest has been focused on metabolites that can function as osmolytes, the accumulation of which decreases the freezing point within the cell and prevents the dehydration of the cytoplasm. Low-molecular-weight osmolytes, including glycinebetaine, organic acids, sugars, polyalcohols, amino acids such as proline, polyamines, quaternary ammonium compounds, etc., have a crucial role in sustaining cellular function during low temperature stress (Páldi et al., 1998; Folkert et al., 2001). Osmolytes are involved in the regulation of cellular water homeostasis, the reduction of cellular dehydration, and the stabilization of enzymes, membranes and other cellular components.

Plants may also tolerate frost through extracellular ice formation in the apoplasts, where it does not have the lethal consequences it would have within the cell. Antifreeze proteins are found in a wide range of overwintering plants, where they inhibit the growth and recrystallization of ice that forms in the intercellular spaces (Griffith and Yaish, 2004).

It is thus clear that investigations on compounds capable of reducing the stress sensitivity of plants are of great importance. Salicylic acid (SA), a phenolic compound produced by a wide range of plant species, may participate in many physiological and metabolic reactions in plants. It was first demonstrated to play a role in responses to biotic stress (Raskin, 1992). Later it became increasingly clear that SA may also play a role in the plant response to abiotic stressors. It was first found that the application of SA in satisfactory concentrations induced stress tolerance in various plant species, as demonstrated for example for heat (Dat et al., 1998), cold (Janda et al., 1999) or heavy metal stress (Krantev et al., 2008). Then a rise in the endogenous SA levels was detected in several plant species exposed to unfavourable environmental conditions (Pál et al., 2005; Horváth et al., 2007). There is evidence that this hormone regulates processes such as seed germination, vegetative growth, photosynthesis, respiration, thermogenesis, flower formation, seed production, 
senescence, and a type of cell death that is not associated with the hypersensitive response. In addition, SA may play a role in maintaining cellular redox homeostasis through the regulation of antioxidant enzyme activity and the induction of the alternative respiratory pathway. Furthermore, it may also regulate gene expression by inducing an RNA-dependent RNA polymerase that is important for posttranscriptional gene silencing (Rivas-San Vicente and Plasencia, 2011). The present paper provides a review of recent results on the effects of SA and related compounds in processes leading to acclimation to low temperatures.

\section{Exogenous SA and related compounds may alleviate the cold-induced injury in plants}

The fact that SA may provide protection against low temperature injury in plants was first demonstrated when the addition of $0.5 \mathrm{mM} \mathrm{SA}$ to the hydroponic growth solution of maize seedlings under normal growth conditions substantially reduced the damage symptoms of a subsequent chilling stress. Besides the obvious visual symptoms, this observation was confirmed by chlorophyll- $a$ fluorescence parameters and measurements of electrolyte leakage from the leaves (Janda et al., 1997; 1999). Among the antioxidant enzymes, the activity of catalase decreased, while that of glutathione reductase and guaiacol peroxidase increased as a result of preliminary treatment with SA. These changes might at least partially explain the increased cold tolerance. Earlier results showed that $\mathrm{H}_{2} \mathrm{O}_{2}$ may also improve the cold tolerance of maize plants without cold acclimation via the activation of certain antioxidant defence systems (Prasad et al., 1994a;b). Similar results have been published recently on rice, where treatment with a low level of $\mathrm{H}_{2} \mathrm{O}_{2}$ caused a significant reversal in the oxidative damage to the newly assembled membrane system resulting from heat or chilling stress, together with an up-regulation of antioxidative defence systems (Bhattacharjee, 2012). In Arabidopsis plants treated with $\mathrm{SA}, \mathrm{H}_{2} \mathrm{O}_{2}$ levels increased up to 3-fold as a result of the inactivation of the $\mathrm{H}_{2} \mathrm{O}_{2}$-degrading enzymes catalase and ascorbate peroxidase (Rao et al., 1997). Further studies proved that not only SA, but also its putative precursors, benzoic acid (BA) and ortho-hydroxy-cinnamic acid (oHCA), and other related compounds such as aspirin or 2,6-dihydroxy BA may have a protective role against chilling stress in young maize plants (Janda et al., 1998; 2000; Horváth et al., 2002). Similarly, not only SA, but other related compounds, such as 2,6-dihydroxy BA or aspirin (acetyl-SA), hastened the germination of carrot seeds at $5^{\circ} \mathrm{C}$ (Rajasekaran et al., 2002). It should also be mentioned, however, that these compounds, like SA, may cause severe damage to the plants when applied above a certain concentration at normal growth temperature: a significant decrease was detected in the photosynthetic capacity and the growth rate. When SA concentrations higher than $1 \mathrm{mM}$ were added to the hydroponic solution of maize, the 
appearance of anthocyanin could be observed in the leaves, especially in the light, and root viability decreased after a few days, eventually leading to the death of the plants (Janda et al., 1998; 2000; Pál et al., 2002).

In addition to the above stimulatory but dose-dependent effects of SA were reported in embryogenic cell suspension cultures of Coffea arabica L. treated with picomolar concentrations of SA; however, the higher concentrations did not have a significant effect on cellular growth (Quiroz-Figueroa et al., 2001). The foliar application of SA or aspirin enhanced stomatal conductance, transpiration and photosynthetic rates in both soybean and maize (Khan et al., 2003). SA was able to regulate the leaf photosynthetic functions of cucumber seedlings and enhance seedling resistance to low temperature and light intensity. The optimum concentration of SA for foliar spraying was $1 \mathrm{mM}$ (Liu et al., 2009).

Pre-treatment of the leaves of chilling-sensitive banana seedlings with 0.5 $\mathrm{mM}$ SA solution by spraying the foliage or irrigating the roots also induced an increase in chilling tolerance during subsequent chilling stress. This, as found previously in maize (Janda et al., 1999), was accompanied by a change in the activity of antioxidant enzymes (Kang et al., 2003a). Furthermore, although SA pre-treatment at $30 / 22^{\circ} \mathrm{C}$ resulted in $\mathrm{H}_{2} \mathrm{O}_{2}$ accumulation, it reduced $\mathrm{H}_{2} \mathrm{O}_{2}$ overproduction during the subsequent $5^{\circ} \mathrm{C}$ chilling stress in banana (Kang et al., 2003b). However, SA treatment itself resulted in many changes in the ultrastructure of banana cells, such as the separation of the cells from palisade parenchymas, the appearance of crevices in the cell walls, the swelling of grana and stromal thylakoids, and a reduction in the number of starch granules (Kang et al., 2007). These results demonstrated that under normal conditions SA treatment could also act as a stress factor (Fig. 1).

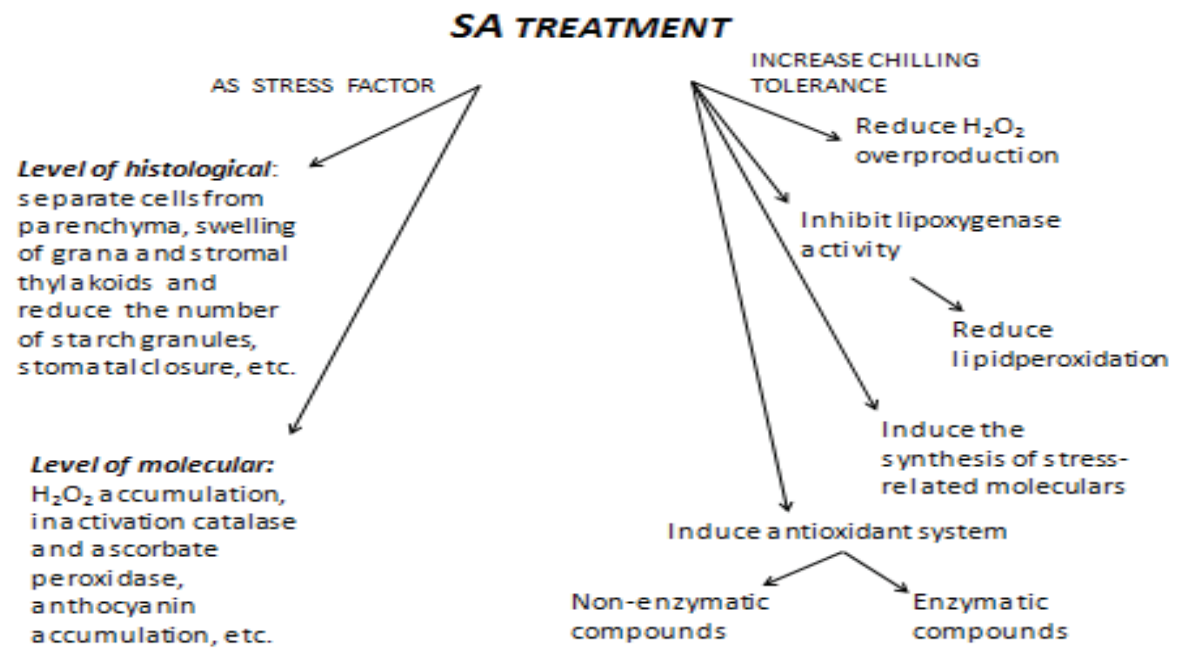

Fig. 1. Generalised model of the dual action of SA in plants. For details, see text. 
Treating seeds before sowing in $0.1-0.5 \mathrm{mM}$ SA or aspirin could also be an effective way of improving cold tolerance in tomato and bean plants (Senaratna et al., 2000). Priming pepper (Capsicum annuum L.) seeds in a solution containing aspirin at a concentration range of $0.05-0.5 \mathrm{mM}$ is a useful method to increase the germination percentage and the germination at low temperature (Korkmaz, 2005). Soaking bean (Phaseolus vulgaris L.) seeds in 0.1 $\mathrm{mM}$ SA solution also significantly improved the germination percentage, germination rate and seedling criteria under optimal and low temperature stress conditions (Gharib and Hegazi, 2010). Furthermore, seed priming with SA improved seedling emergence, root and shoot length, seedling fresh and dry weights, and leaf and root scores compared to the control both at optimal and chilling temperatures in maize (Farooq et al., 2008). The chilling tolerance of leaves or hypocotyls was also significantly increased by the application of 0.5 mM SA in cucumber and rice (Kang and Saltveit, 2002), but this improved chilling tolerance was only observed in the leaves of rice and in the hypocotyl of cucumber, as exposure to SA caused a significant reduction in the growth of the radicle. The inhibitory effect of SA on radicle growth did not appear if SA application started at germination, suggesting that seedlings may become acclimated to SA (Kang and Saltveit, 2002). Treatment of wheat seeds with SA before sowing also stimulated the growth of plant shoots and roots, as evident from the increase in both their weights and lengths (Rakhmankulova et al., 2010). This effect was accompanied by a considerable decrease in the content of endogenous SA, especially its free active form and particularly in the shoots, and a gradual increase in the proportion of the alternative cyanide-resistant respiration pathway and a reduction in cytochrome respiration in the shoots. In the root tissues, positive morphophysiological and biochemical changes were observed: stronger growth stimulation, an increase in the proportion of the cytochrome respiration pathway and the suppression of alternative respiration, and an improvement in the antioxidant balance, which was manifested as a reduced level of lipid peroxidation. Experiments using radioactively labelled SA and gene expression studies showed that soaking pea seeds in SA solution before sowing may increase productivity and induce de novo SA synthesis (Szalai et al., 2011).

SA was able to reduce lipid peroxidation through the inhibition of lipoxygenase activity and a decline in the $\mathrm{H}_{2} \mathrm{O}_{2}$ content, leading to the maintenance of cellular membrane integrity under stress conditions (Lapenna et al., 2009). Treatment of the plants with SA also affected the activity of enzymes related to the carbon metabolism, such as RuBisCO and carbonic anhydrase (Pancheva and Popova, 1998; Slaymaker et al., 2002).

The effect of SA in alleviating chilling injury in peach during cold storage may be attributed to its ability to induce antioxidant systems, including enzymatic and non-enzymatic compounds (Wang and Li, 2006). A $2 \mathrm{mM}$ concentration of SA was highly effective in reducing chilling injury in 
pomegranate fruit (Sayyari et al., 2009). SA was more effective in increasing the chilling tolerance of cucumber seedlings when applied in the form of seed soaking than as a foliar spray and the best protection appeared to be obtained for seedlings from seed soaked in SA at 0.5 or $1 \mathrm{mM}$ (Sayyari, 2012). In contrast, in rice, which usually contains a very high level of endogenous SA, pre-treatment with $0.5,1.0$ or $2.0 \mathrm{mM} \mathrm{SA}$ before exposure to low temperature decreased the chilling tolerance of the plants. It is probable that the down-regulation of the antioxidant defence system might be involved in the reduction of chilling tolerance (Wang et al., 2009a).

All these results show that it is always necessary to investigate the best method of SA application and the dose giving maximum protection, as a function of the plant species, the growth stage and the plant organ treated.

The positive effect of SA was shown not only during chilling but also under freezing conditions. Cryopreservation is a more valuable technique for the long-term in vitro conservation of plant germplasm, since the metabolism ceases to function when frozen in liquid nitrogen, so tissues are maintained without growth and no genetic alterations take place even during a very long period of storage. SA significantly enhanced the viability percentage of encapsulated embryonic axes of Persian lilac (Melia azedarach L.) when they were subjected either to the cryopreservation technique, involving dehydration and freezing in liquid nitrogen, or to cold preservation by storing alginate beads at low, but nonfreezing temperature (Bernard et al., 2002). Spraying wheat leaves with SA had an effect similar to that of cold acclimation, causing an increase in ice nucleation activity under cold and control conditions. These results show that SA can increase freezing tolerance by affecting apoplastic proteins (Taşgín et al., 2003). In rye, however, the apoplastic proteins induced by SA did not have antifreeze activity (Yu et al., 2001), and only treatment with ethylene induced antifreeze activity in winter rye leaves. The SA analogue 4-hydroxybenzoic acid ameliorated the freezing tolerance of the spring wheat Chinese Spring (Horváth et al., 2007). It is hypothesized that 4-hydroxybenzoic acid increases the impermeability of the cell wall, leading to increased resistance to pathogen infection. The reinforcement of the cell wall by 4-hydroxybenzoic acid may also contribute to increased tolerance against freezing stress. The SA-induced increase in the activity of certain antioxidant enzymes during the cold hardening period has also been described in wheat plants (Sasheva et al., 2010).

Another related compound, methyl SA (MeSA), increased resistance to chilling injury in freshly harvested green bell pepper (Capsicum annuum L.) when used at a final vapour concentration of $0.1 \mathrm{mM}$ for 1 day at room temperature (Fung et al., 2004). The alternative respiratory pathway may moderate chilling injury by keeping the production of ROS in balance with the levels of antioxidants and active oxygen-scavenging enzyme systems. The expression patterns of alternative oxidase and of several other genes involved in the defence against oxidative stress before and during the early chilling period 
suggested that the pre-treatment of pepper fruit with methyl SA vapours preferentially increased the transcript levels of alternative oxidase and that this increase was correlated with chilling tolerance. The increased capacity to produce respiratory heat after exposure to chilling temperatures may also contribute to the cold-acclimation process (Moynihan et al., 1995).

Although MeSA was proposed as a putative mobile signal in plant defence (Park et al., 2007), its possible practical use is much less documented than that of the non-volatile compound SA. The emission of MeSA, and occasionally of methylbenzoate, from Arabidopsis thaliana leaves was detected following the application of some forms of both biotic and abiotic stresses to the plant. Systemic acquired resistance requires the translocation of one or more mobile signals from the site of infection through the vascular system to distal (systemic) tissues. The signal identified was MeSA in tobacco (Nicotiana tabacum), Arabidopsis and potato (Solanum tuberosum) (Liu et al., 2011). Many carnivorous arthropods use herbivore-induced plant volatiles to locate their prey. It is often unknown which compounds in such a complex volatile blend represent the signal to the foraging carnivore. MeSA is part of the volatile blend in the foraging behaviour of the predatory mite (Phytoseiulus persimilis). This compound is one of those released by lima bean infested with Tetranychus urticae, a prey species of the predatory mite. MeSA attracted satiated predatory mites in a dose-dependent way with optimum attraction at a dose of $0.2 \mu \mathrm{g}$ (De Boer and Dicke, 2004). Interplant communication has been widely demonstrated in plants, especially in herbaceous plants. In neighbouring intact cuttings, three volatiles, methyl jasmonate, MeSA and benzothiazole, were detected in the volatiles emitted from mechanically damaged poplar cuttings. The results also suggest that the entire defence response of plants involves a variety of airborne signals in wound-induced volatiles (Hu et al., 2009).

\section{Changes in endogenous SA content during cold stress}

Chilling-induced SA accumulation, particularly that of conjugated SA, was reported in both the leaves and roots of rice cultivars (Wang et al., 2009b). When the endogenous SA content was monitored after SA treatment in the leaves and crowns of two wheat cultivars differing in cold tolerance, SA was found to accumulate in a concentration-dependent manner in the roots of both cultivars, conjugated SA accounting for most of the increase (Wang et al., 2006). In another experiment when wheat plants were exposed to low non-freezing temperature $\left(4^{\circ} \mathrm{C}\right)$, the SA level significantly decreased in the leaves of a winter wheat variety, but this was followed by a pronounced increase in SA, with a maximum after 7 days (Kosová et al., 2012). These data are in accordance with those of Janda et al. (2007), who found increases in both free and bound SA and in its precursor $o \mathrm{HCA}$ in winter wheat. However, after prolonged cold treatment, a gradual decrease in SA may also occur. In the leaves of a spring wheat variety, 
the SA profile basically followed the same trend, but the changes in SA levels were less pronounced (Kosová et al., 2012). A decrease in the SA level was also observed in the crowns of winter wheat after 1 day, followed by a peak between 3 and 7 days. Prolonged cold treatment was associated with a decrease in SA. In the crowns of the spring variety, the down-regulation of SA was much more pronounced than in the winter one, a minimum being detected after 3 days, when a gradual elevation of SA began. This latter increase might be related to the function of SA in regulating ROS evolution, which is an important part of plant stress defences (Kosová et al., 2012).

Cold acclimation also increased the frost tolerance in androgenic genotypes of Festulolium (Festuca $\times$ Lolium hybrids), where resistant genotypes were characterized by higher concentrations of abscisic acid and lower concentrations of SA than susceptible genotypes during the first few days of cold acclimation (Pociecha et al., 2009). However, after prolonged cold acclimation, the content of phenolics was significantly lower in genotypes tolerant to freezing than in susceptible genotypes, while the activity of the phenylalanine ammonia-lyase enzyme was significantly higher. Plant growth substances such as abscisic acid, cytokinins or gibberellic acid also modify the response of plants to low temperature stress (Pál et al., 2011; Majláth et al., 2012). Furthermore, the treatment of wheat seeds with SA caused the accumulation of abscisic acid and indoleacetic acid (Shakirova et al., 2002), and this effect may also have a direct or indirect role in the altered tolerance to low temperature stress. These results support the view that signalling networks controlling acclimation to low temperature conditions involve the regulation of foliar concentrations of abscisic acid and SA levels during successful cold acclimation.

The use of mutants and transgenic plants in which the synthesis, accumulation or translocation of SA is modified could help to clarify its role under stress conditions. It is important to emphasise, however, that in many cases the results achieved using Arabidopsis as a model plant can only be generalised to a limited extent, making them unsuitable for the interpretation of stress adaptation processes, especially in genetically distant plant species such as monocotyledonous cereals. The growth of Arabidopsis plants under chilling conditions could be related to their SA levels. Wild-type and transgenic NahG Arabidopsis plants that carry the salicylate hydroxylase gene (which converts SA to catechol) and usually have a low level of SA, had similar assimilation rates under optimum temperatures. At low temperature, however, $N a h G$ plants displayed relative growth rates about one-third greater than the wild type, due primarily to greater cell expansion in the $N a h G$ rosette leaves and a higher net assimilation rate (Scott et al., 2004). At $5^{\circ} \mathrm{C}$ wild-type shoots accumulated SA, particularly in bound, glucosylated form. The growth and SA levels were also examined in SA-signalling and metabolism mutants at $5^{\circ} \mathrm{C}$. The partially SAinsensitive nprl mutant (non-expresser of SA-inducible PR genes) displayed 
growth intermediate between that of $N a h G$ and the wild type, while the eds 5 mutant (inhibited SA transport from the chloroplast) behaved like $N a h G$. These results suggest that salicylate accumulation inhibits growth at chilling temperature in Arabidopsis plants. A negative correlation was found between the growth rate under cold conditions and the levels or perception of SA.

\section{Concluding remarks}

In conclusion, SA has a contradictory role in cold stress tolerance. Although exogenous SA treatment can protect plants against stress-induced injury, the treatment itself may also cause stress to the control plants. Furthermore, SA treatment may also alter the endogenous SA metabolism, either by inducing de novo synthesis or, depending on the plant species, plant organ or environmental conditions, by decreasing it. Since changes in SA have been reported in the case of various types of stresses, it is possible that changes in the SA level in plants exposed to low temperature conditions is part of a general stress response rather than a stress-specific acclimation process. As discussed above, the effect of SA is highly dependent on several factors, including the plant species, the mode of application, the dose, and the environmental conditions. Therefore, it is hardly possible to create a general scheme to describe how SA may act in plants. However, in general it can be said that several processes, described in various experiments, may explain the possible protective effect of SA. The altered antioxidant capacity is one of the most frequent explanations; however, several other stress-related processes, including changes in the expression rates of certain genes, play a role in acclimation. In spite of the fact that there are still several open questions about the exact role of SA in stress acclimation signalling processes, SA and/or its related compounds seem to have the potential to improve the stress tolerance of the crop plants grown by farmers.

\section{Acknowledgements}

This work was funded by the Hungarian Scientific Research Fund (OTKA PD83840, K101367). Magda Pál is the recipient of a János Bolyai Scholarship.

\section{References}

Bernard, F., Shaker-Bazarnov, H. Kaviani, B. (2002): Effects of salicylic acid on cold preservation and cryopreservation of encapsulated embryonic axes of Persian lilac (Melia azedarach L.). Euphytica, 123, 85-88.

Bhattacharjee, S. (2012): An inductive pulse of hydrogen peroxide pretreatment restores redoxhomeostasis and oxidative membrane damage under extremes of temperature in two rice cultivars. Plant Growth Regul., 68, 395-410.

Dat, J. F., Lopez-Delgado, H., Foyer, C. H., Scott, I. M. (1998): Parallel changes in $\mathrm{H}_{2} \mathrm{O}_{2}$ and catalase during thermotolerance induced by salicylic acid or heat acclimation in mustard seedlings. Plant Physiol., 116, 1351-1357. 
De Boer, J. G., Dicke, M. (2004): The role of methyl salicylate in prey searching behavior of the predatory mite Phytoseiulus persimilis. J. Chem. Ecol., 30, 255-271.

Farooq, M., Aziz, T., Basra, S. M. A., Cheema, M. A., Rehman, H. (2008): Chilling tolerance in hybrid maize induced by seed priming with salicylic acid. J. Agron. Crop Sci., 194, 161-168.

Folkert, A. H., Elena, A. G., Buitink, J. (2001): Mechanisms of plant desiccation tolerance. Trends Plant Sci., 6, 431-438.

Fung, R. W. M., Wang, C. Y., Smith, D. L., Gross, K. C., Tian, M. S. (2004): MeSA and MeJA increase steady-state transcript levels of alternative oxidase and resistance against chilling injury in sweet peppers (Capsicum annuum L.). Plant Sci., 166, 711-719.

Gharib, F. A., Hegazi, A. Z. (2010): Salicylic acid ameliorates germination, seedling growth, phytohormone and enzymes activity in bean (Phaseolus vulgaris L.) under cold stress. $J$. Am. Sci., 6, 675-683.

Griffith, M., Yaish, M. W. (2004): Antifreeze proteins in overwintering plants: a tale of two activities. Trends Plant Sci., 9, 399-405.

Horváth, E., Janda, T., Szalai, G., Páldi, E. (2002): In vitro salicylic acid inhibition of catalase activity in maize: differences between the isozymes and a possible role in the induction of chilling tolerance. Plant Sci., 163, 1129-1135.

Horváth, E., Pál, M., Szalai, G., Páldi, E., Janda, T. (2007): Exogenous 4-hydroxybenzoic acid and salicylic acid modulate the effect of short-term drought and freezing stress on wheat plants. Biol. Plant.., 51, 480-487.

Hu, Z., Shen, Y., Shen, F., Luo, Y., Su, X. (2009): Evidence for the signaling role of methyl jasmonate, methyl salicylate and benzothiazole between poplar (Populus simonii $\times P$. pyramidalis 'Opera 8277') cuttings. Trees, 23, 1003-1011.

Janda, T., Szalai, G., Antunovics, Z., Ducruet, J. M., Páldi, E. (1998): Effects of salicylic acid and related compounds on photosynthetic parameters in young maize (Zea mays L.) plants. pp. 3869-3872. In: Garab, G. (ed)., Photosynthesis: Mechanisms and Effects. Kluwer Acad. Publ., Dordrecht.

Janda, T., Szalai, G., Antunovics, Z., Horváth, E., Páldi, E. (2000): Effect of benzoic acid and aspirin on chilling tolerance and photosynthesis in young maize plants. Maydica, 45, 29-33.

Janda, T., Szalai, G., Leskó, K., Yordanova, R., Apostol, S., Popova, L. P. (2007): Factors contributing to enhanced freezing tolerance in wheat during frost hardening in the light. Phytochemistry, 68, 1674-1682.

Janda, T., Szalai, G., Tari, I., Páldi, E. (1997): Exogenous salicylic acid has an effect on chilling symptoms in maize (Zea mays L.) plants. In: Sowinski, P., Zagdanska, B., Aniol, A., Klaus, P. (eds.), Crop Development for Cool and Wet European Climate. ECSP-EEC-EAEC, Brussels, Belgium. pp. 179-187.

Janda, T., Szalai, G., Tari, I., Páldi, E. (1999): Hydroponic treatment with salicylic acid decreases the effect of chilling injury in maize (Zea mays L.) plants. Planta, 208, 175-180.

Kang, G. Z., Wang, C. H., Sun, G. C., Wang, Z. X. (2003a): Salicylic acid changes activities of $\mathrm{H}_{2} \mathrm{O}_{2}$-metabolizing enzymes and increases the chilling tolerance of banana seedlings. Environ. Exp. Bot., 50, 9-15.

Kang, G. Z., Wang, Z. X., Sun, G. C. (2003b): Participation of $\mathrm{H}_{2} \mathrm{O}_{2}$ in enhancement of cold chilling by salicylic acid in banana seedlings. Acta Bot. Sin., 45, 567-573.

Kang, G. Z., Wang, Z. X., Xia, K. F., Sun, G. C. (2007): Protection of ultrastructure in chillingstressed banana leaves by salicylic acid. J. Zhejiang Univ. Sc. B., 8, 277-282.

Kang, H. M., Saltveit, M. E. (2002): Chilling tolerance of maize, cucumber and rice seedling leaves and roots are differentially affected by salicylic acid. Physiol. Plant., 115, 571-576.

Khan, W., Prithiviraj, B., Smith, D. L. (2003): Photosynthetic responses of corn and soybean to foliar application of salicylates. J. Plant Physiol., 160, 485-492.

Korkmaz, A. (2005): Inclusion of acetyl salicylic acid and methyl jasmonate into the priming solution improves low temperature germination and emergence of sweet pepper. HortScience, 40, 197-200. 
Kosová, K., Prášil, I. T., Vítámvás, P., Dobrev, P., Motyka, V., Floková, K., Novák, O., Turečková, V., Rolčik, J., Pešek, B., Trávnicková, A., Gaudinová, A., Galiba, G., Janda, T., Vlasáková, E., Prášilová, P., Vanková, R. (2012): Complex phytohormone responses during the cold acclimation of two wheat cultivars differing in cold tolerance, winter Samanta and spring Sandra. J. Plant Physiol., 169, 567-576.

Krantev, A., Yordanova, R., Janda, T., Szalai, G., Popova, L. (2008): Treatment with salicylic acid decreases the effect of cadmium on photosynthesis in maize plants. J. Plant Physiol., 165, 920-931.

Lapenna, D., Ciofani, G., Pierdomenico, S. D., Neri, M., Cuccurullo, C., Giambernardino, M. A., Cuccurullo, F. (2009): Inhibitory activity of salicylic acid on lipoxygenase-dependent lipid peroxidation. Biochim. Biophys. Acta, 1790, 25-30.

Liu, P. P., von Dahl, C. C., Park, S. W., Klessig, D. F. (2011): Interconnection between methyl salicylate and lipid-based long-distance signaling during the development of systemic acquired resistance in Arabidopsis and tobacco. Plant Physiol. 155, 1762-1768.

Liu, W., Ai, X. Z., Liang, W. J., Wang, H. T., Liu, S. X., Zheng, N. (2009): Effects of salicylic acid on the leaf photosynthesis and antioxidant enzyme activities of cucumber seedlings under low temperature and light intensity. Chinese J. Appl. Ecol., 20, 441-445.

Lukatkin, A. S., Brazaitytè, A., Bobinas, Č., Duchovskis, P. (2012): Chilling injury in chillingsensitive plants: a review. Agriculture, 99, 111-124.

Majláth, I., Szalai, G., Soós, V., Sebestyén, E., Balázs, E., Vanková, R., Dobrev, P. I., Tandori, J., Janda, T. (2012): Effect of light on the gene expression and hormonal status of winter and spring wheat plants during cold hardening. Physiol. Plant., 145, 296-314.

Moynihan, M. R., Ordentlich, A., Raskin, I. (1995): Chilling-induced heat evolution in plants Plant Physiol., 108, 995-999.

Pál, M., Horváth, E., Janda, T., Páldi, E., Szalai, G. (2005): Cadmium stimulates accumulation of salicylic acid and its putative precursors in maize (Zea mays L.) plants. Physiol. Plant., 125, 356-364.

Pál, M., Janda, T., Szalai, G. (2011): Abscisic acid may alter the salicylic acid-related abiotic stress response in maize. J. Agron. Crop Sci., 197, 368-377.

Pál, M., Szalai, G., Horváth, E., Janda, T., Páldi, E. (2002): Effect of salicylic acid during heavy metal stress. Acta Biol. Szegediensis, 46, 119-120.

Páldi, E., Szalai, G., Janda, T., Marton, L. C. (1998): Az alacsony hőmérséklet hatása egyes Ntartalmú vegyületek szintézisére különböző hidegtürésủ beltenyésztett kukorica vonalakban. (The effect of low temperature on N-containing compounds synthesis in different coldtolerance inbred maize lines.) Növénytermelés, 47, 483-490.

Pancheva, T. V., Popova, L. P. (1998): Effect of salicylic acid on the synthesis of ribulose-1,5bisphosphate carboxylase/oxygenase in barley leaves. J. Plant Physiol., 152, 381-386.

Park, S. W., Kaimoyo, E., Kumar, D., Mosher, S., Klessig, D. F. (2007): Methyl salicylate is a critical mobile signal for plant systemic acquired resistance. Science, 318, 113-116.

Pociecha, E., Płażek, A., Janowiak, F., Waligórski, P., Zwierzykowski, Z. (2009): Changes in abscisic acid, salicylic acid and phenylpropanoid concentrations during cold acclimation of androgenic forms of Festulolium (Festuca pratensis $\times$ Lolium multiflorum) in relation to resistance to pink snow mould (Microdochium nivale). Plant Breeding, 128, 397-403.

Prasad, T. K., Anderson, M. D., Martin, B. A., Stewart, C. R. (1994a): Evidence for chillinginduced oxidative stress in maize seedlings and a regulatory role for hydrogen peroxide. Plant Cell, 6, 65-74.

Prasad, T. K., Anderson, M. D., Stewart, C. R. (1994b): Acclimation, hydrogen peroxide, and abscisic acid protect mitochondria against irreversible chilling injury in maize seedlings. Plant Physiol., 105, 619-627.

Quiroz-Figueroa, F., Mendez-Zeel, M., Larque-Saavedra, A., Loyola-Vargas, V. M. (2001): Picomolar concentrations of salicylates induce cellular growth and enhance somatic embryogenesis in Coffea arabica tissue culture. Plant Cell Rep., 20, 679-684.

Rajasekaran, L. R., Stiles, A., Caldwell, C. D. (2002): Stand establishment in processing carrots. Effects of various temperature regimes on germination and the role of salicylates in promoting germination at low temperatures. Can. J. Plant Sci., 82, 443-450. 
Rakhmankulova, Z. F., Fedyaev, V. V., Rakhmatulina, S. R., Ivanov, C. P., Gilvanova, I. R., Usmanov, I. Y. (2010): The effect of wheat seed presowing treatment with salicylic acid on its endogenous content, activities of respiratory pathways, and plant antioxidant status. Russ. J. Plant Physiol., 57, 778-783.

Rao, M. V., Paliyath, G., Ormrod, D. P., Murr, D. P., Watkins, C. B. (1997): Influence of salicylic acid on $\mathrm{H}_{2} \mathrm{O}_{2}$ production, oxidative stress, and $\mathrm{H}_{2} \mathrm{O}_{2}$-metabolizing enzymes. Plant Physiol., 115, 137-149.

Raskin, I. (1992): Role of salicylic acid in plants. Annu. Rev. Plant Physiol. Plant Mol. Biol., 43, 439-463.

Rivas-San Vicente, M., Plasencia, J. (2011): Salicylic acid beyond defence: its role in plant growth and development. J. Exp. Bot., 62, 3321-3338.

Sasheva, P., Szalai, G., Janda, T., Popova, L. (2010): Study of the behaviour of antioxidant enzymes in the response to hardening and freezing stress in two wheat (Triticum aestivum L.) varieties. Cr. Acad. Bulg. Sci., 63, 1733-1740.

Sayyari, M. (2012): Improving chilling resistance of cucumber seedlings by salicylic acid. American-Eurasian J. Agric. \& Environ. Sci., 12, 204-209.

Sayyari, M., Babalare, M., Kalantarie, S., Serranoc, M., Valero, D. (2009): Effect of salicylic acid treatment on reducing chilling injury in stored pomegranates. Postharvest Biol. Tech., 53, 152-154.

Scott, I. M., Clarke, S. M., Wood, J. E., Mur, L. A. J. (2004): Salicylate accumulation inhibits growth at chilling temperature in Arabidopsis. Plant Physiol., 135, 1040-1049.

Senaratna, T., Touchell, D., Bunn, E., Dixon, K. (2000): Acetyl salicylic acid (Aspirin) and salicylic acid induce multiple stress tolerance in bean and tomato plants. Plant Growth Regul., 30, 157-161.

Shakirova, F. M., Sakhabutdinova, A. R., Bezrukova, M. V., Fatkhutdinova R. A., Fatkhutdinova, D. R. (2002): Changes in the hormonal status of wheat seedlings induced by salicylic acid and salinity. Plant Sci., 164, 317-322.

Slaymaker, D. H., Navarre, D. A., Clark, D., del Pozo, O., Martin, G. B., Klessig, D. F. (2002): The tobacco salicylic acid-binding protein 3 (SABP3) is the chloroplast carbonic anhydrase, which exhibits antioxidant activity and plays a role in the hypersensitive defense response. PNAS, 99, 11640-11645.

Szalai, G., Janda, T., Páldi, E., Dubacq, J. P. (2001): Changes in the fatty acid unsaturation after hardening in wheat chromosome substitution lines with different cold tolerance. J. Plant Physiol., 158, 663-666.

Szalai, G., Horgosi, S., Soós, V., Majláth, I., Balázs, E., Janda, T. (2011): Salicylic acid treatment of pea seeds induces its de novo synthesis. J. Plant Physiol., 168, 213-219.

Taşgín, E., Atící, Ö., Nalbantoğlu, B. (2003): Effects of salicylic acid and cold on freezing tolerance in winter wheat leaves. Plant Growth Regul., 41, 231-236.

Wang, D. H., Li, X. X., Su, Z. K., Ren, H. X. (2009a): The role of salicylic acid in response of two rice cultivars to chilling stress. Biol. Plant., 53, 545-552,

Wang, L., Chena, S., Kong, W., Li, S., Archbold, D. D. (2006): Salicylic acid pretreatment alleviates chilling injury and affects the antioxidant system and heat shock proteins of peaches during cold storage. Postharvest Biol. Technol., 41, 244-251.

Wang, L. J., Li, S. L. (2006): Salicylic acid-induced heat or cold tolerance in relation to $\mathrm{Ca}^{2+}$ homeostasis and antioxidant systems in young grape plants. Plant Sci., 170, 685-694.

Wang, Y., Bao, Z. L., Zhu, Y., Hua, J. (2009b): Analysis of temperature modulation of plant defense against biotrophic microbes. Mol. Plant Microbe Int., 22, 498-506.

Yadav, S. K. (2010): Cold stress tolerance mechanisms in plants. A review. Agron. Sustain. Dev., 30, 515-527.

Yu, X. M., Griffith, M., Wiseman, S. B. (2001): Ethylene induces antifreeze activity in winter rye leaves. Plant Physiol., 126, 1232-1240.

Corresponding author: M. Pál

Phone: +36-22-569-502

E-mail:pal.magda@agrar.mta.hu 